\title{
Classification of new phytoplasmas associated with diseases of strawberry in Florida, based on analysis of 16S rRNA and ribosomal protein gene operon sequences
}

\author{
Rasa Jomantiene, ${ }^{1}$ Robert E. Davis, ${ }^{1}$ John Maas $^{2}$ and Ellen L. Dally ${ }^{1}$ \\ Author for correspondence: Robert E. Davis. Tel: + 1301504 5745. Fax: + 13015045449. \\ e-mail: rdavis@astr.arsusda.gov
}

Molecular Plant Pathology Laboratory ${ }^{1}$ and Fruit Laboratory², Agricultural Research Service-USDA, Beltsville, MD 20705, USA

\begin{abstract}
Strawberry plants exhibiting symptoms of stunting and abnormally small leaves were observed in production fields in central Florida, USA. Since the symptoms were suggestive of phytoplasma infection, plants were assayed for presence of phytoplasma by PCR amplification of 165 rDNA and ribosomal protein (rp) gene sequences. Amplification of phytoplasma-specific DNA sequences by PCR indicated infection of the diseased strawberry plants by phytoplasmas. RFLP analyses of amplified 16S rDNA revealed that the plants were infected by two mutually distinct phytoplasmas that differed from strawberry green petal phytoplasma (group 16Srl-C). Both phytoplasmas were members of 165 rRNA gene group I (16Srl). Based on RFLP analysis of amplified 165 rDNA and rp gene sequences, one was classified in group 16Srl subgroup I and new rp subgroup 16Srl-I(rp); its 165 rRNA-rp subgroup was designated 16Srl-K(rr-rp). The second phytoplasma represented a previously undescribed subgroup, designated $K$, in 16S rRNA group I but belonged to rp subgroup $16 \mathrm{Srl}-J(r p)$; this phytoplasma's $16 \mathrm{~S}$ rRNA-rp subgroup was designated 16Srl$J(r r-r p)$. Results of RFLP analyses agreed with putative restriction site maps based on nucleotide sequences determined for the amplified 165 rDNAs and rp gene operon DNAs. Further evidence indicated that the 16SrI-K(rr-rp) strawberry phytoplasma, Mexican periwinkle virescence phytoplasma and stolbur phytoplasma shared sequence homologies that enabled amplification of DNA from all three by PCR using primers previously designed as stolburspecific.
\end{abstract}

Keywords: mycoplasma, multiplier disease

\section{INTRODUCTION}

Strawberry (Fragaria $\times$ ananassa Duch.) is affected by several diseases that are presumed to be caused by phytoplasmas (formerly mycoplasma-like organisms, MLOs). These diseases include green petal, multiplier disease, witches' broom and others (11). Although several diseases and symptom syndromes have been

Abbreviations: AY, Maryland aster yellow; BBS, blueberry stunt; $C X$, Canada X-disease; MPV, Mexican periwinkle virescence; $r p$, ribosomal protein; STOL, stolbur.

The GenBank accession number for the 16S rDNA sequences are U96614 (STRAWB1) and U96616 (STRAWB2) and for the rp gene operon sequences they are U96615 (STRAWB1) and U96617 (STRAWB2). described, little is known about the identity of phytoplasmas that may be causally associated with the diseases.

A possibly phytoplasma-related disease has been observed in strawberry in Florida, USA, where strawberries are grown for fruits primarily for the shipping market. During the winter production season in 1995-6, Florida's strawberry production was in excess of $65000 \mathrm{t}$ of fruit on 2700 ha of land, primarily in central Florida. Although the production represented less than $10 \%$ of the national annual production, its value at the farm gate was approximately $\$ 105$ million (C. Hinton, personal communication). Planting time generally is in October with plants raised in nurseries located north of Florida. Following the end of the 
production season in March, the strawberry plants are destroyed, and the beds are planted with a different crop.

To obtain fruit production in Florida in DecemberMarch, most transplants, which are short-day types that require some chilling to initiate flower buds, are raised in northern areas of North America, especially Canada, where the plants are subjected to cool nights in late summer and early autumn, inducing flower bud initiation. Occasional plants shipped from northern nurseries and transplanted in Florida for fruit production have displayed disease symptoms indicating possible infection by phytoplasma.

Symptoms suggestive of infection by phytoplasmas have been observed in transplanted strawberry plants in Florida since the 1980s. For example, symptoms resembling those of green petal disease have been most evident on flower- and fruit-producing plants in the field in Florida during January-March (C. M. Howard, personal communication). Symptoms similar to those of multiplier disease (11) have also been encountered in transplant material shipped to Florida. The latter symptoms have been observed as early in the cultural scheme as when the plants are removed from shipping containers arriving in Florida in autumn (M. Brown, personal communication).

During the winter fruit production season in 1995-6, symptoms suggestive of possible infection by phytoplasma were again observed in strawberry plants growing in Florida. Since incidence of the disease may have increased over that in the previous production season, the present study was initiated to investigate whether phytoplasmas might be involved. The results indicated that at least two phylogenetically distinct phytoplasmas were associated with disease in the plants (7).

\section{METHODS}

Plant samples and reference phytoplasma strains. Samples of leaves were collected during March 1996 from five naturally infected strawberry plants (cv. Oso Grande) exhibiting symptoms of stunting and small leaves in the field in Florida. One sample (leaves and petioles) was taken from each plant; the samples were labelled StrFL1-StrFL5. Phytoplasmas maintained in plants of periwinkle [Catharanthus roseus L. (G.) Don] and used as references included Maryland aster yellows $(\mathrm{AY}=\mathrm{AY} 1)$, Canada X-disease $(\mathrm{CX})$, Mexican periwinkle virescence $(\mathrm{MPV})$, blueberry stunt $(\mathrm{BBS}=\mathrm{BBS1})$ from Michigan, and stolbur (STOL) phytoplasmas $(6,15)$.

PCR conditions and primers. Nucleic acid for use as template in PCR was extracted from fresh tissue by a previously described method (9). After extraction, DNA was purified using GeneCleanIII kit as specified by the manufacturer (Bio 101).

Five pairs of oligonucleotides were used to prime PCR. $\mathrm{R} 16 \mathrm{mF} 2 / \mathrm{R} 1, \mathrm{R} 16 \mathrm{~F} 2 \mathrm{n} / \mathrm{R} 2$, and $\mathrm{P} 1 / \mathrm{P} 7$, are phytoplasma universal primer pairs $(3,16)$. Primer pair fSTOL/rSTOL was previously designed as a STOL phytoplasma-specific primer pair (12). Oligonucleotide pair $\mathrm{rpF} 1 / \mathrm{R} 1$ primes amplification of phytoplasma ribosomal protein (rp) gene operon sequences $(4,10)$. Both nested and direct, non-nested PCR were used. In nested PCR, DNA amplified in PCR primed by $\mathrm{R} 16 \mathrm{mF} 2 / \mathrm{R} 1$ was diluted $1: 50$ with sterile distilled water and used as template in PCR primed by R16F2n/R2. Primer pairs $\mathrm{P} 1 / \mathrm{P} 7$, fSTOL/rSTOL, and $\mathrm{rpF} 1 / \mathrm{R} 1$ were used in direct, non-nested PCR only. All PCR was carried out in a final volume of $25 \mu$ under conditions as previously described $(4,9,14)$. PCRs were carried out for 35 cycles using the following parameters: $1 \mathrm{~min}$ ( $3 \mathrm{~min}$ for first cycle) denaturation at $94^{\circ} \mathrm{C}$, annealing for $2 \mathrm{~min}$ at $60^{\circ} \mathrm{C}\left(55^{\circ} \mathrm{C}\right.$ for reactions using $\mathrm{R} 16 \mathrm{~F} 2 \mathrm{n} / \mathrm{R} 2$ or $\mathrm{fSTOL} / \mathrm{rSTOL})$, and primer extension for $3 \mathrm{~min}\left(10 \mathrm{~min}\right.$ in final cycle) at $72^{\circ} \mathrm{C}$. Reaction mixtures devoid of templates were included in all experiments as negative controls. Resulting PCR products were analysed by electrophoresis through $1 \%$ agarose gel, stained with ethidium bromide, and DNA bands visualized using a UV transilluminator. DNA fragment size standard was $1 \mathrm{~kb}$ ladder (Life Technologies).

RFLP analyses of amplified phytoplasma DNA. Products from nested PCR primed by $\mathrm{R} 16 \mathrm{~F} 2 \mathrm{n} / \mathrm{R} 2$ or non-nested PCR primed by $\mathrm{rpF} 1 / \mathrm{R} 1$ were analysed by single enzyme digestion, according to manufacturers' instructions, with $A l u \mathrm{I}$, HhaI, KpnI (Life Technologies) and MseI, HpaI, HpaII, RsaI, Sau3AI, HaeIII, HinfI, DraI (New England Biolabs). The RFLP profile of digested DNA was analysed by electrophoresis through $5 \%$ (for analyses of amplified $16 \mathrm{~S}$ rDNA) and 5 or $8 \%$ (for analyses of amplified ribosomal protein gene operon sequences) polyacrylamide gels, staining in ethidium bromide, and visualization using a UV transilluminator. DNA fragment size standards used were PhiX174 RF HaeIII digest (Life Technologies) and $1.6 \mathrm{~kb}$ ladder (MBI Fermentas). RFLP patterns were compared with those obtained using reference phytoplasmas in this study and with RFLP patterns previously published $(9,18)$.

Nucleotide sequencing and putative restriction site analysis. PCR-amplified 16S rRNA gene and rp gene operon products were sequenced using standard dideoxy chain-termination methods. The nucleotide sequences determined in this study were deposited in the GenBank database. Other sequences used in this study were obtained from GenBank. Gene sequences from strawberry phytoplasmas detected in this study and from STOL (GenBank accession no. X76427) and Michigan aster yellows (MIAY, virescence of Oenothera hookeri) (GenBank accession nos M30790 and M74770) (10, 12) phytoplasmas were analysed to identify recognition sequences for selected restriction enzymes. Putative restriction site maps were generated by using the DNASTAR program MapDraw option (DNASTAR). Alignment of pairs of sequences were generated and sequence similarities evaluated by using the DNASTAR program Align option.

\section{RESULTS}

\section{Detection and analysis of phytoplasma 165 rDNA in diseased strawberry}

Based on amplification of $16 \mathrm{~S}$ rDNA in nested PCR primed by phytoplasma universal primer pairs, phytoplasmas were detected in all five symptomatic strawberry plants examined. The five phytoplasma strains were named STRAWB1 through STRAWB5, respectively, according to the number designation of the plant in which each was detected. Assignment of the phytoplasmas to groups and subgroups was accomplished initially by RFLP analysis of amplified 16S rDNA 
Table 1. Classification of phytoplasmas from diseased strawberries and of reference phytoplasmas used in this study

\begin{tabular}{|c|c|c|c|c|}
\hline Phytoplasma & $\begin{array}{l}\text { 16S rRNA } \\
\text { group and } \\
\text { subgroup }\end{array}$ & rp subgroup & $\begin{array}{l}\text { 16S rRNA-rp } \\
\text { subgroup }\end{array}$ & Reference \\
\hline \multicolumn{5}{|l|}{ Strawberry } \\
\hline STRAWB1 & $16 \mathrm{SrI}-\mathrm{I}$ & $16 \operatorname{SrI}-\mathrm{I}(\mathrm{rp})$ & 16SrI-K(rr-rp) & This paper \\
\hline STRAWB2 & $16 \mathrm{SrI}-\mathrm{K}$ & $16 \mathrm{SrI}-J(\mathrm{rp})$ & $16 \mathrm{SrI}-J(\mathrm{rr}-\mathrm{rp})$ & This paper \\
\hline \multicolumn{5}{|l|}{ Reference* } \\
\hline STOL & $16 \mathrm{SrI}-\mathrm{G}$ & Undetermined & Undetermined & \\
\hline MPV & $16 \mathrm{SrI}-\mathrm{I}$ & 16SrI-H(rp) & $16 \mathrm{SrI}-\mathrm{I}(\mathrm{rr}-\mathrm{rp})$ & (5) \\
\hline BBS & $16 \mathrm{SrI}-\mathrm{E}$ & 16SrI-E(rp) & 16SrI-E(rr-rp) & (5) \\
\hline
\end{tabular}

*STOL, stolbur phytoplasma; MPV, Mexican periwinkle virescence phytoplasma; BBS, blueberry stunt phytoplasma from Michigan.

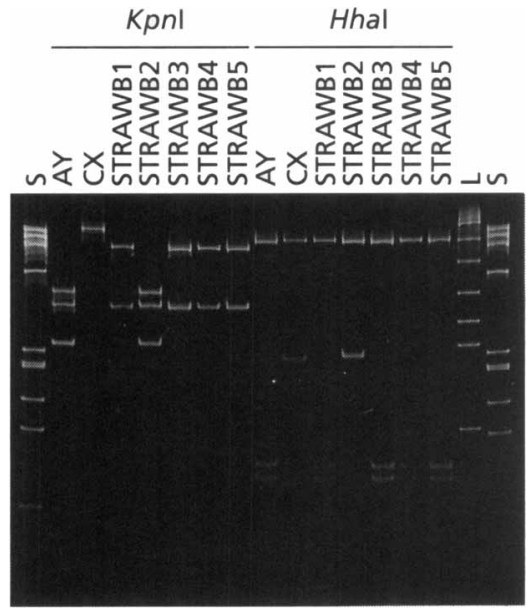

Fig. 1. Kpnl and Hhal RFLP profiles of phytoplasma 16S rDNA amplified in nested PCRs primed by oligonucleotide pair $F 2 n / R 2$ from five diseased strawberry plants in Florida. S, $\phi \times 174$, Haell digest, size standard; $L, 1.6 \mathrm{~kb}$ ladder, size standard; $A Y$, Maryland aster yellows phytoplasma; CX, Canada X-disease phytoplasma. Phytoplasmas detected in the five different plants were designated STRAWB1-5.

from reactions primed by primer pair $\mathrm{R} 16 \mathrm{~F} 2 \mathrm{n} / \mathrm{R} 2$. Results from two strawberry phytoplasma strains are summarized in Table 1. RFLPs observed following digestion of amplified DNAs with KpnI and HhaI revealed that the five strawberry plants were infected by phytoplasmas of two types (Fig. 1). Four plants were infected by apparently similar phytoplasma strains, whereas the fifth plant was infected by a different phytoplasma. Digestion of the amplified DNAs by $K p n I$ indicated that all five phytoplasmas detected were affiliated with $16 \mathrm{~S}$ rRNA gene group $16 \mathrm{SrI}$ (aster yellows and related phytoplasmas), since digestion of $16 \mathrm{~S} \mathrm{rDNA}$ by $\mathrm{KpnI}$ is characteristic of phytoplasmas affiliated with this group (9). RFLP patterns obtained after digestion of rDNA with other enzymes were also consistent with classification of the strawberry phytoplasmas in group 16SrI (Fig. 2). Fig. 2a shows RFLP patterns of 16S rDNA amplified from strain STRAWB1 in PCRs primed by F2n/R2. The collective RFLP patterns of 16S rDNA from strains STRAWB3, STRAWB4 and STRAWB5 (data not shown) were indistinguishable from those of $16 \mathrm{~S}$ rDNA from strain STRAWB1 and indicated that these four strains could be classified in group $16 \mathrm{SrI}$ subgroup I (type strain MPV) (5). Since strains STRAWB1, STRAWB3, STRAWB4 and STRAWB5 were indistinguishable by this method, one strain, STRAWB1, was selected as representative for further work.

Since STRAWB1 and MPV phytoplasmas were not distinguished on the basis of RFLP analysis of DNA amplified by PCR primed by $\mathrm{F} 2 \mathrm{n} / \mathrm{R} 2$, a separate experiment to obtain a larger rRNA gene fragment was carried out. In this case, DNA was amplified in PCR primed by P1/P7. RFLP analysis of this approx. $1.7 \mathrm{kbp}$ DNA using HaeIII and HpaII distinguished between STRAWB1 and MPV phytoplasma (data not shown).

In contrast to the other four phytoplasmas detected in diseased strawberry plants, phytoplasma STRAWB2 could not be assigned to any previously described subgroup in group 16SrI. The AluI RFLP pattern of amplified 16S rDNA from phytoplasma STRAWB2 differed from that of all known reference phytoplasmas except BBS, but the HpaII RFLP pattern distinguished STRAWB2 from BBS phytoplasma (Fig. 2b). Phytoplasma STRAWB2 was assigned to a new 16SrRNA subgroup, which we designate $\mathrm{K}$.

\section{STOL-specific primers in PCR}

In a parallel study, N. A. Harrison (University of Florida, Ft Lauderdale) detected a phytoplasma in strawberry with symptoms of green petal in Florida and found that, in comparisons with other phytoplasmas, the nucleotide sequence of the 16S-23S rRNA gene spacer region from the phytoplasma was 

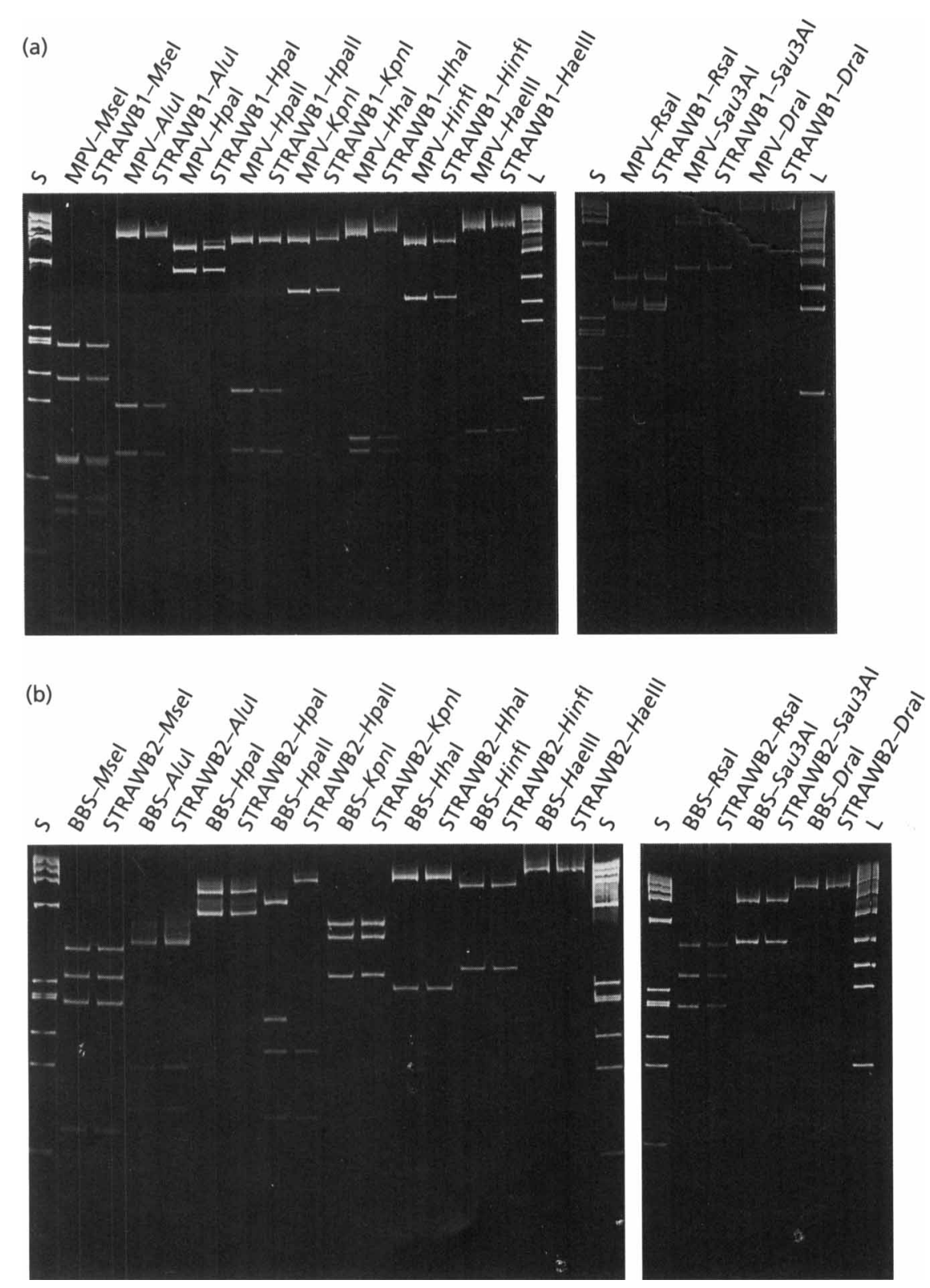

Fig. 2. RFLP analysis of 165 rDNA amplified in nested PCRs primed by oligonucleotide pair R16F2n/R2 from phytoplasmas infecting naturally diseased plants of strawberry in Florida. First round PCR was primed by R16mF2/R1 followed by reamplification of target DNA in nested PCR primed by $\mathrm{R} 16 \mathrm{~F} 2 \mathrm{n} / \mathrm{R} 2$. DNA products from the second, nested PCR were digested with restriction endonucleases Msel, Alul, Hpal, Hpall, Kpni, Hhal, Hinfl, Haelll, Rsal, Sau3Al or Dral and separated by electrophoresis through $5 \%$ polyacrylamide gels. STRAWB1, Phytoplasma detected in naturally diseased, symptomatic strawberry plant StrFL1; STRAWB2, phytoplasma detected in naturally diseased, symptomatic strawberry plant StrFL2. (a) STRAWB1 and MPV (b) STRAWB2 and BBS. Other abbreviations are the same as for Fig. 1.

most similar to that of STOL phytoplasma (N. A. Harrison, personal communication). We wished to determine whether the phytoplasmas in the strawberry plants in our study might contain a similar phytoplasma. Previously, PCR primers (fSTOL/rSTOL) were designed for specific detection of STOL phytoplasma (12). In the present work, use of this oligonucleotide primer pair in PCR resulted in amplification of an approximately $550 \mathrm{bp}$ phytoplasmaspecific DNA in reaction mixtures containing template DNA derived from STOL and MPV phytoplasmas and from strawberry phytoplasmas STRAWB1 and STRAWB3 (Fig. 3). In contrast, no DNA amplification was observed when template DNA was derived from strawberry phytoplasma STRAWB2 (Fig. 3). These results indicated that portions of rRNA operon sequences of phytoplasmas STRAWB1 and
STRAWB3, as well as of MPV phytoplasma, may be more closely similar to those of STOL phytoplasma than are those of AY and STRAWB2 phytoplasmas.

\section{Amplification and RFLP analysis of phytoplasma rp gene operon sequences}

Further analysis for identification of phytoplasmas in the diseased strawberry plants from Florida was accomplished by amplification and RFLP analysis of rp gene operon sequences. Use in PCR of a primer pair previously designed to prime amplification of phytoplasma rp gene sequences (10) resulted in amplification of a phytoplasma-characteristic $1.3 \mathrm{kbp}$ DNA in the case of phytoplasma STRAWB1 and STRAWB3, but amplification of an approximately $1.2 \mathrm{kbp}$ DNA was observed in the case of phytoplasma STRAWB2 and 


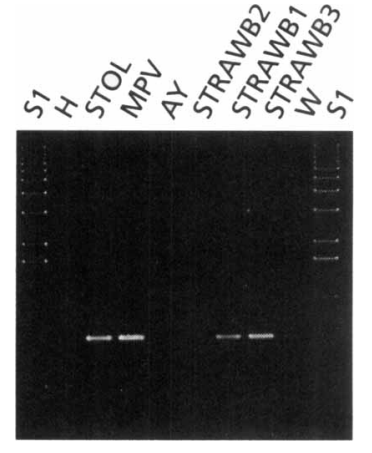

Fig. 3. Amplification of phytoplasma DNA sequences in PCRs primed by primer pair fSTOL/rSTOL. $H$, Healthy periwinkle; STOL, stolbur reference phytoplasma from Capsicum annuum in Serbia; AY, Maryland aster yellows phytoplasma; STRAWB3, phytoplasma detected in naturally diseased strawberry plant StrFL3; W, reaction mixture devoid of template DNA; $\mathbf{S 1}, 1 \mathrm{~kb}$ ladder size standard. Other abbreviations are the same as for Fig. 2.

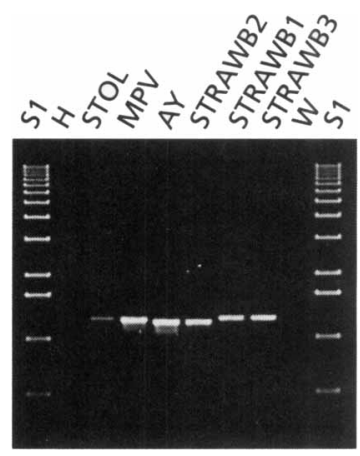

Fig. 4. Amplification of phytoplasma rp gene operon sequences in PCRs primed by primer pair rpF1/R1. Abbreviations are the same as for Fig. 3.

AY (Fig. 4). Interestingly, amplification of an approximately $1.3 \mathrm{kbp}$ DNA was also observed when reaction mixtures contained template DNA derived from MPV and STOL phytoplasmas.

Our RFLP analyses of amplified 16S rDNA had indicated that STRAWB1 and STOL belonged to two different 16S rRNA subgroups. Since both STRAWB1 and MPV belonged to the same 16S rRNA subgroup, rp gene operon sequences were amplified from MPV and subjected to MseI and $A l u \mathrm{I}$ RFLP analyses for side by side comparisons with RFLP patterns of rp sequences from STRAWB1 (Fig. 5). Based on collective RFLP patterns of the amplified rp gene operon sequences, strain STRAWB1 was distinguished from MPV phytoplasma and was classified in a previously undescribed rp gene subgroup, designated rp subgroup 16SrI-I(rp) (Table 1). When amplified rp gene operon sequences were analysed using $M s e \mathrm{I}$ and $A l u \mathrm{I}$, collective RFLP patterns of DNA from STRAWB2 were the same as those observed for BBS phytoplasma (Fig.

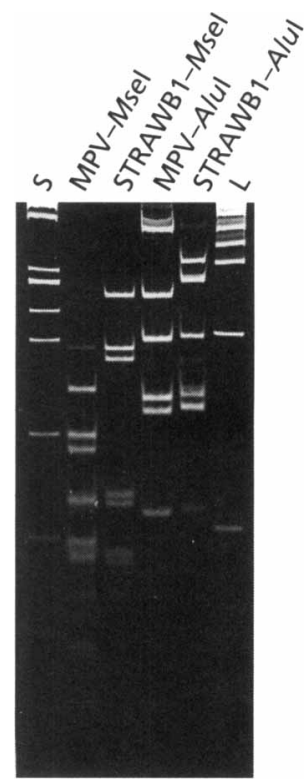

Fig. 5. RFLP analysis of rp gene operon sequences amplified in PCRs primed by oligonucleotide pair rpF1/R1 from phytoplasma STRAWB1 detected in naturally diseased strawberry in Florida. Products from digestion with restriction enzymes were separated by electrophoresis through a $8 \%$ polyacrylamide gel. Abbreviations are the same as for Fig. 2.

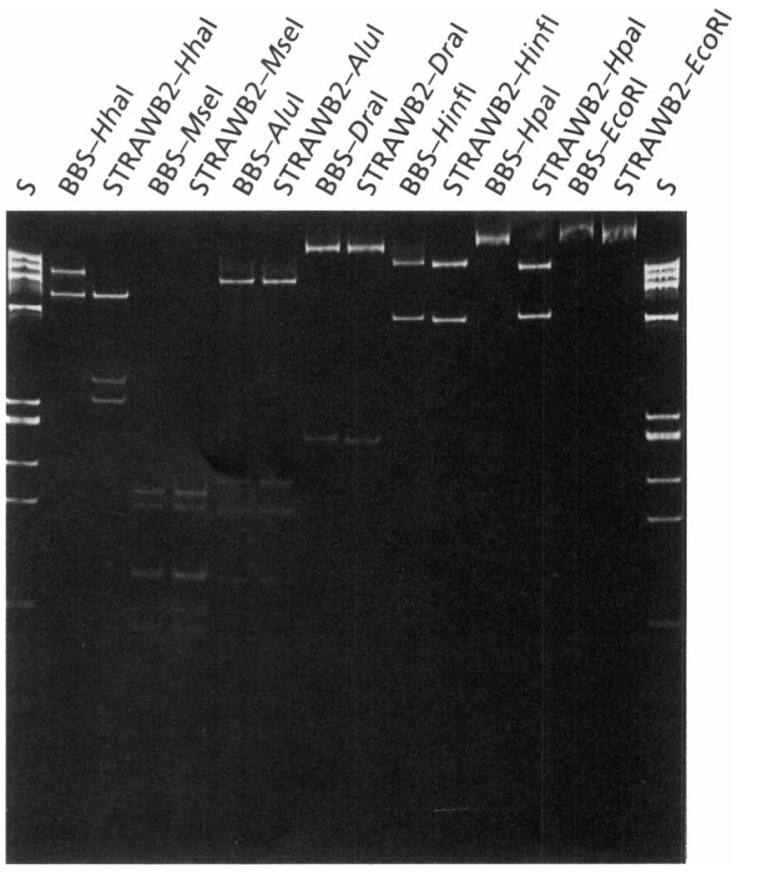

Fig. 6. RFLP analysis of rp gene operon sequences amplified in PCRs primed by oligonucleotide pair rpF1/R1 from phytoplasma STRAWB2 detected in naturally diseased strawberry in Florida. Products from digestion with restriction enzymes were separated by electrophoresis through a $5 \%$ polyacrylamide gel. Abbreviations are the same as for Fig. 2.

6). Since BBS phytoplasma is a member of rp subgroup 16SrI-E (5), these results indicated that STRAWB2 might belong to rp subgroup $16 \mathrm{SrI}-\mathrm{E}(\mathrm{rp})$. However, 

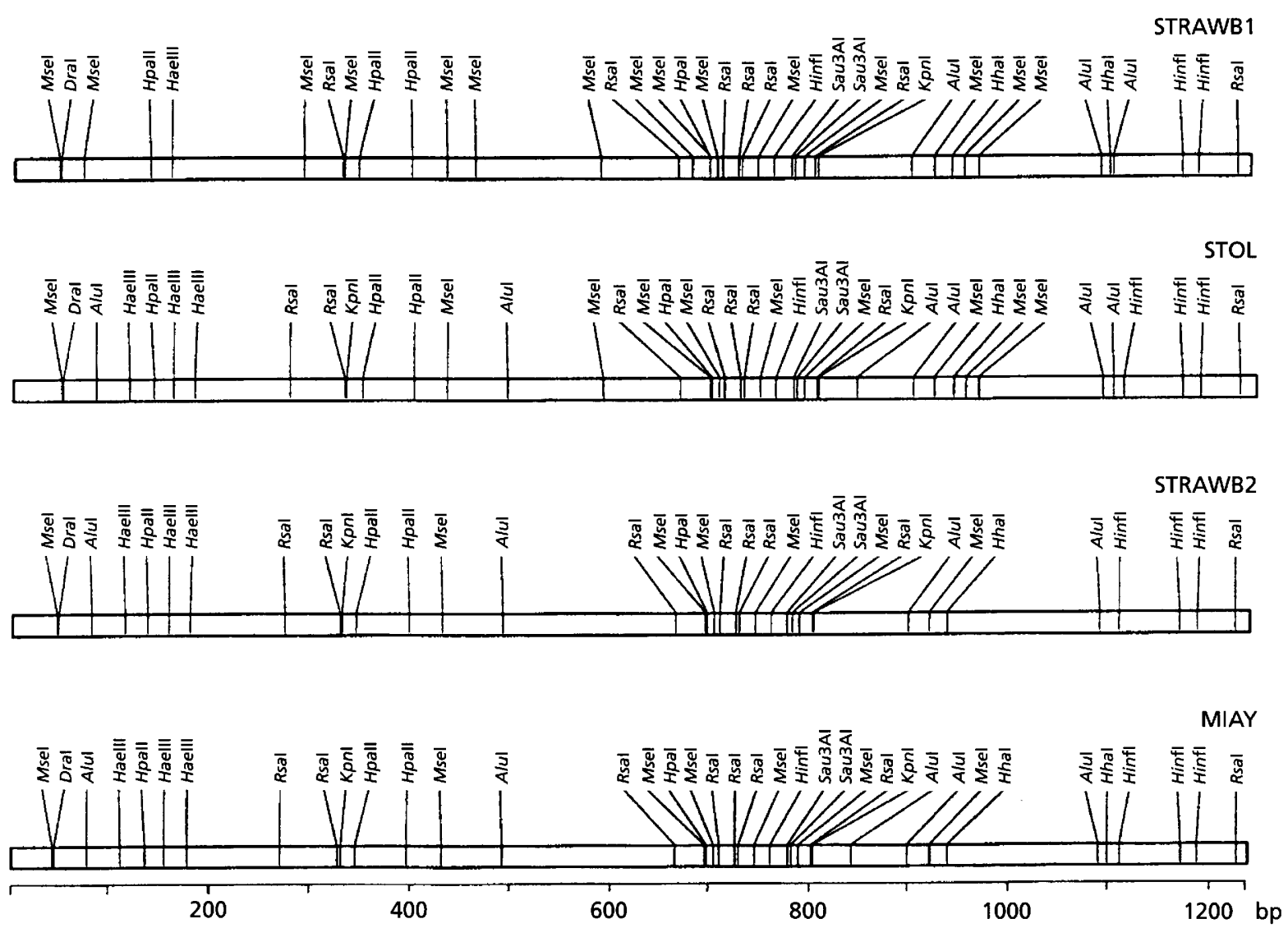

Fig. 7. Analysis of putative restriction sites of phytoplasma 16S rRNA gene sequences. Maps were generated using the MapDraw option of the DNASTAR program (DNASTAR) and manually aligned for comparison of recognition sites for restriction endonucleases. STRAWB1, Phytoplasma detected in naturally diseased strawberry plant StrFL1; STRAWB2, phytoplasma detected in naturally diseased strawberry plant StrFL2; STOL, stolbur reference phytoplasma from Capsicum annuum in Serbia; MIAY, reference phytoplasma Michigan aster yellows.

use of HhaI and HpaI in the RFLP analysis distinguished STRAWB2 from BBS phytoplasma (Fig. 6). On the basis of these results, phytoplasma STRAWB2 was classified as representative of a new rp subgroup designated 16SrI-J(rp) (Table 1).

\section{Nucleotide sequences and putative restriction sites in amplified 16S rRNA and rp gene operon sequences}

Results from comparative analysis of putative restriction sites in the sequenced DNAs are shown in Figs 7 and 8. Expected fragment sizes based on analysis of putative restriction sites were in excellent agreement with fragment sizes obtained by enzymic RFLP analysis of amplified 16S rDNA from STRAWB1 and STRAWB2 (Fig. 7) and the rp gene operon sequence from STRAWB1 and STRAWB2 (Fig. 8). Strawberry phytoplasmas STRAWB1 and STRAWB2 were distinguished from one another by the restriction site analyses of $16 \mathrm{~S}$ rDNA and rp gene operon sequences. Both strawberry phytoplasmas were distinguished from STOL by the restriction site analysis of $16 \mathrm{~S}$ rDNA (Fig. 7). Sequence similarity of 16S rDNA from STRAWB1 with aligned 16S rDNA from STRAWB2 was about $95 \cdot 1 \%$. Sequence similarity of $16 \mathrm{~S}$ rDNA from STRAWB1 with aligned 16S rDNA from STOL was about $95 \cdot 2 \%$. Sequence similarity of $16 \mathrm{~S}$ rDNA from STRAWB2 with aligned $16 \mathrm{~S}$ rDNA from STOL was about $94 \cdot 7 \%$. These levels of sequence similarity indicate that the three phytoplasmas are mutually distinct.

\section{DISCUSSION}

Recently, Harrison et al. (6) reported the presence of three mutually distinguishable phytoplasmas in diseased plants of strawberry in Florida. One was comparable in RFLP patterns of amplified DNAs to clover phyllody and strawberry green petal phytoplasmas and was classified as a member of phytoplasma 16S rRNArr-rp group 16SrI, subgroup C [16SrI-C(rr-rp)] (6). The remaining two phytoplasmas were classified, respectively, as members of group 16SrI-I(rr-rp) (MPV and related phytoplasmas) and of a new, undesignated, subgroup in group 16SrI(rr-rp) (6). Our results also indicate that diseased strawberries in Florida were infected by phytoplasmas belonging to $16 \mathrm{~S}$ rRNA group 16SrI. In contrast to the work by 

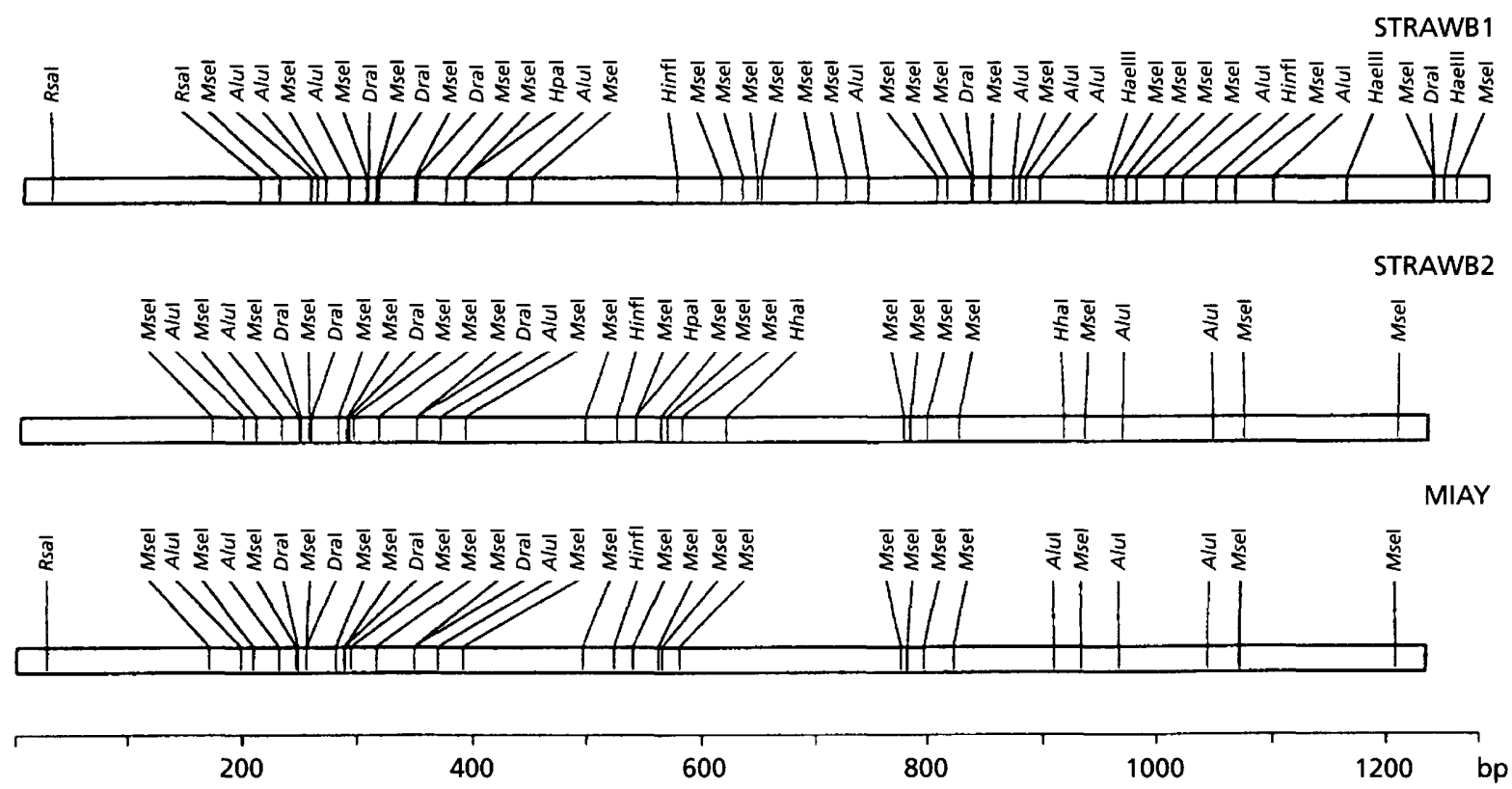

Fig. 8. Analysis of putative restriction sites of phytoplasma ribosomal protein gene operon sequences. Maps were generated as for Fig. 7. STRAWB1, Phytoplasma detected in naturally diseased strawberry plant StrFL1; STRAWB2, phytoplasma detected in naturally diseased strawberry plant StrFL2; MIAY, reference phytoplasma Michigan aster yellows.

Harrison et al. (6), neither phytoplasma STRAWB1 nor STRAWB2 encountered in our study belongs to $16 \mathrm{SrI}-\mathrm{C}(\mathrm{rr}-\mathrm{rp})$ or to $16 \mathrm{SrI}-\mathrm{I}(\mathrm{rr}-\mathrm{rp})$. Based on the description of the unclassified new phytoplasma reported by Harrison et al. (6), it was not possible to assess whether or not it is related to either STRAWB1 or STRAWB2. Neither of the two mutually distinguishable group 16SrI phytoplasmas discovered in strawberry in the present study has been described previously.

Whereas STRAWB1 and MPV phytoplasmas were not distinguished from each other by analysis of DNA amplified in PCR using F2n/R2, it was interesting that these phytoplasmas could be distinguished from each other on the basis of RFLP analysis of a longer rDNA sequence that was amplified in PCR primed by $\mathrm{P} 1 / \mathrm{P} 7$. These results indicated that phytoplasma classifications of finer distinction may be aided by RFLP analyses of sequences that include the $3^{\prime}$ end of the $16 \mathrm{~S}$ rRNA gene, the 16S-23S rRNA gene spacer region, and the $5^{\prime}$ end of the 23S rRNA gene in RFLP analyses, as in the case of DNA amplified by PCR using P1/P7.

Comparisons of collective RFLP patterns of amplified rp gene operon sequences from phytoplasma STRAWB2 with those of reference phytoplasmas, and with patterns previously published (5), indicated similarities between STRAWB2 and BBS phytoplasma. Among known phytoplasmas, STRAWB2 was most similar to BBS in rp gene operon RFLPs, but RFLP patterns of $16 \mathrm{~S}$ rDNA indicated that these phytoplasmas belong to two mutually distinct subgroups in
$16 \mathrm{~S}$ rRNA group I. When only $M s e \mathrm{I}$ and $A l u \mathrm{I}$ were used in RFLP analyses of amplified rp gene operon sequences as in previous work (5), it was not possible to distinguish between STRAWB2 and BBS phytoplasmas, and it appeared that RFLP analysis of $16 \mathrm{~S}$ rRNA gene sequences made it possible to distinguish two phytoplasmas that were not distinguished on the basis of RFLP analyses of, generally more variable (17), rp gene sequences. However, use of HhaI and $\mathrm{HpaI}$ in the analyses of amplified rp gene operon sequences revealed that STRAWB2 and BBS were distinct from one another, reinforcing the importance of using several enzymes for RFLP analyses of phytoplasma DNA.

Recent findings on phytoplasma 16S-23S rRNA gene spacer region sequences $(16 ; \mathrm{N}$. A. Harrison, personal communication) are also of interest in view of results from work to identify and classify strawberry infecting phytoplasmas (this paper and 6). For example, in a simultaneous study, a phytoplasma infecting strawberry in Florida was classified in 16S rRNA subgroup 16SrI-I and rr-rp subgroup 16SrI-I (rr-rp) (type strain, MPV phytoplasma) based on RFLP analyses of PCRamplified DNA (6). The $16 \mathrm{~S}-23 \mathrm{~S}$ rRNA gene spacer region sequences were very similar between this strawberry phytoplasma and STOL phytoplasma (N. A. Harrison, personal communication). These findings are interesting beyond their relevance to strawberry, since STOL and a related phytoplasma have been implicated in diseases that include grapevine yellows in Europe and Australia $(2,13)$, but neither 'Candidatus Phytoplasma australiense' nor STOL phytoplasma 
has been reported in North America. The 16S-23S rRNA gene spacer region sequences have been used to establish phylogenetic relationships of plant-pathogenic phytoplasmas (8) and to design phytoplasmaspecific PCR primers (16). Analysis of this spacer region might be expected to make finer distinctions among phytoplasmas than analysis of $16 \mathrm{~S}$ rDNA, since the spacer region generally exhibits greater sequence variation (1). Yet, although their spacer region sequences are very similar $(\mathrm{N}$. A. Harrison, personal communication), STOL phytoplasma is classified in a $16 \mathrm{~S}$ rRNA subgroup, namely $16 \mathrm{SrI}-\mathrm{G}$ (18; R. E. Davis \& A. Bertaccini, unpublished), different from that of MPV phytoplasma. Thus, while the 16S-23S rRNA gene spacer region can be highly useful for the design of phytoplasma group-specific PCR primers (16), in some cases primers capable of finer distinctions undoubtedly will be required to distinguish particular phytoplasmas of quarantine or epidemiological significance.

The distinction made in this study between STRAWB1, MPV and STOL phytoplasmas is significant, because the use in PCR of primer fSTOL/rSTOL, previously described as STOL-specific (12), resulted in the amplification of DNA from all three of these phytoplasmas. Our conclusion that these phytoplasmas are affiliated with two different 16S rRNA subgroups and probably three different rr-rp subgroups is consistent with significant phylogenetic divergence, as comprehensive phylogenetic studies have revealed for other phytoplasmas $(4,5,15)$. This paper and our previous communication (2) present the first results indicating that primer pair fSTOL/rSTOL is not completely specific for STOL phytoplasma, since it primes amplification of DNA from North American and Australian phytoplasmas that are phylogenetically distinct from STOL phytoplasma. Therefore, DNA amplification primed by fSTOL/rSTOL in the present work provided no evidence that STOL phytoplasma is present in North America. These findings illustrate that studies of phytoplasma host range and disease aetiology should not depend entirely on the use of this primer pair in PCR, but should be accompanied by other procedures for phytoplasma identification.

This study describes two new phytoplasmas and establishes strawberry as a host for both. Although their possible causal relationships with disease symptoms in strawberry have not been established, partial characterization of new phytoplasmas in strawberries in this and a related study (6) provides background that should prove useful for further studies on the epidemiology and control of strawberry diseases.

\section{ACKNOWLEDGEMENTS}

We thank Kristi Bottner for excellent technical assistance; N. A. Harrison for fruitful discussions; and N. A. Harrison, D. Ramsdell and E. Seemüller for providing reference phytoplasmas used in this study. This work was supported by grant no. US-2335-93 from BARD, the United States-Israel Binational Research \& Development Fund.

\section{REFERENCES}

1. Barry, T., Colleran, G., Glennon, M., Dunican, L. K. \& Gannon, F. (1991). The $16 \mathrm{~S} / 23 \mathrm{~S}$ ribosomal spacer region as a target for DNA probes to identify eubacteria. PCR Methods Appl 1, 51-56.

2. Davis, R. E., Dally, E. L., Gundersen, D. E., Lee, I.-M. \& Habili, N. (1997). 'Candidatus Phytoplasma australiense', a new phytoplasma taxon associated with Australian grapevine yellows. Int J Syst Bacteriol 47, 262-269.

3. Gundersen, D. E. \& Lee, I.-M. (1996). Ultrasensitive detection of phytoplasmas by nested-PCR assays using two universal primer pairs. Phytopathol Mediterr 35, 144-151.

4. Gundersen, D. E., Lee, I.-M., Rehner, S. A., Davis, R. E. \& Kingsbury, D. T. (1994). Phylogeny of mycoplasmalike organisms (phytoplasmas): a basis for their classification. $J$ Bacteriol 176, 5244-5254.

5. Gundersen, D. E., Lee, I.-M., Schaff, D. A., Harrison, N. A., Chang, C. J., Davis, R. E. \& Kingsbury, D. T. (1996). Genomic diversity and differentiation among phytoplasma strains in 16S rRNA group I (aster yellows and related strains) and group III (peach X-disease and related strains). Int $J$ Syst Bacteriol 46, 64-75.

6. Harrison, N. A., Legard, D. E., DiBonito, R. \& Richardson, P. A. (1997). Detection and differentiation of phytoplasmas associated with diseases of strawberry in Florida. Plant Dis $\mathbf{8 1}$, 230.

7. Jomantiene, R., Davis, R. E., Maas, J. \& Dally, E. L. (1996). Phytoplasmas associated with disease of strawberry in Florida. Phytopathology 86, S123.

8. Kirkpatrick, B. C., Smart, C., Gardner, S., Gao, J.-L., Ahrens, U., Mäurer, R., Schneider, B., Lorenz, K.-H., Seemüller, E., Harrison, N., Namba, S. \& Daire, X. (1994). Phylogenetic relationships of plant pathogenic MLOs established by 16/23S rDNA spacer sequences. IOM Lett 3, 228-229.

9. Lee, I.-M., Hammond, R. W., Davis, R. E. \& Gundersen, D. E. (1993). Universal amplification and analysis of pathogen $16 \mathrm{~S}$ rDNA for classification and identification of mycoplasmalike organisms. Phytopathology 83, 834-842.

10. Lim, P.-O. \& Sears, B. B. (1992). Evolutionary relationships of a plant pathogenic mycoplasmalike organism and Acholeplasma laidlawii deduced from two ribosomal protein gene sequences. J Bacteriol 174, 2606-2611.

11. Maas, J. L. (editor) (1984). Compendium of Strawberry Diseases. St Paul, MN: APS Press.

12. Maixner, M., Ahrens, U. \& Seemüller, E. (1995). Detection of the German grapevine yellows (Vergilbungskrankheit) MLO in grapevine, alternative hosts, and a vector by a specific PCR procedure. Eur J Plant Pathol 101, 241-250.

13. Padovan, A. C., Gibb, K. S., Bertaccini, A., Vibio, M., Bonfiglioli, R. E., Magarey, P. A. \& Sears, B. B. (1995). Molecular detection of the Australian grapevine yellows phytoplasma and comparison with grapevine yellows phytoplasmas from Italy. Aust $J$ Grape Wine Res 1, 25-31.

14. Schaff, D. A., Lee, I.-M. \& Davis, R. E. (1992). Sensitive detection and identification of mycoplasmalike organisms by polymerase chain reactions. Biochem Biophys Res Commun 186, 1503-1509.

15. Seemüller, E., Schneider, B., Mäurer, R., Ahrens, U., Daire, X., Kison, H., Lorenz, K.-H., Firrao, G., Avinent, L., Sears, B. B. \& Stackebrandt, E. (1994). Phylogenetic classification of phytopathogenic mollicutes by sequence analysis of $16 \mathrm{~S}$ ribosomal DNA. Int $J$ Syst Bacteriol 44, 440-446. 
16. Smart, C. D., Schneider, B., Blomquist, C. L., Guerra, L. J., Harrison, N. A., Ahrens, U., Lorenz, K.-H., Seemüller, E. \& Kirkpatrick, B. C. (1996). Phytoplasma-specific PCR primers based on sequences of the $16 \mathrm{~S}-23 \mathrm{~S}$ rRNA spacer region. Appl Environ Microbiol 62, 2988-2993.

17. Toth, K. F., Harrison, N. A. \& Sears, B. B. (1994). Phylogenetic relationships among members of the class Mollicutes deduced from rps3 gene sequences. Int J Syst Bacteriol 44, 119-124.

18. Vibio, M., Bertaccini, A., Lee, I.-M., Davis, R. E. \& Clark, M. F. (1996). Differentiation and classification of aster yellows and related European phytoplasmas. Phytopathol Mediterr $35,33-42$. 